\title{
Intensity of menopausal symptoms and quality of life in climacteric women
}

\author{
Zdzisława C. Szadowska-Szlachetka ${ }^{1}$, Elżbieta Stasiak ${ }^{1}$, Anna Leziak², Anna Irzmańska-Hudziak, \\ Marta Łuczyk ${ }^{1}$, Andrzej Stanisławek ${ }^{1}$, Barbara Ślusarska ${ }^{1}$, Renata Domżał-Drzewicka ${ }^{1}$ \\ ${ }^{1}$ Chair of Oncology and Environmental Health, Faculty of Nursing and Health Sciences, Medical University of Lublin, Poland \\ ${ }^{2} \mathrm{~A}$ graduate of the Faculty of Health Sciences, Medical University of Lublin, Poland
}

\begin{abstract}
Menopause is a difficult period in a woman's life, associated not only with the end of menstruation, but also with symptoms such as hot flashes, sweating, dizziness, and palpitations which occur due to fluctuations in the hormones oestrogen and progesterone. The aim of this study was to evaluate the quality of life of women (aged 48-55 years) in the physical, mental and social spheres, to determine the intensity of menopause symptoms and to ascertain whether the above indicators are influenced by sociodemographic factors. The study was conducted by diagnostic survey using two tools - the WHOQOL-BREF questionnaire for the measurement of the quality of life and the Kupperman index, which measures the severity of menopause symptoms. A total of 161 women not using hormone replacement therapy were examined. In their case, the intensity of menopause symptoms was moderate. The respondents assessed their functioning in the social sphere with the highest number of points (3.65) and in the physical sphere with the lowest number of points (3.14). The intensity of menopause symptoms positively correlated with the evaluation of the quality of life by the respondents. Higher assessment of the quality of life was reported by women working in a given period of time, with good material status, sexually active. The respondents suffered from chronic diseases, most often arterial hypertension. The occurrence of chronic diseases - arterial hypertension, coronary artery disease, diabetes and osteoporosis negatively affected the quality of life of the respondents.
\end{abstract}

Key words: menopause, quality of life, chronic diseases.

\section{Introduction}

Menopause is a complex phenomenon influenced by numerous factors. According to the World Health Organization, menopause occurs when menstruation ceases due to physiological ovarian atrophy and menstruation periods have not occurred for 12 months. Nowadays, it is assumed that the age at which menopause occurs in women in Poland is 49 years of age [1]. The most burdensome symptoms associated with menopause include hot flashes, profuse sweating, dizziness, and palpitations, which result from drastic fluctuations of oestrogen and progesterone levels [2]. Experiencing the symptoms of menopause is individual and depends on the influence of many factors, not just hormonal changes, but also external factors, e.g. living conditions, general health, social functioning and the perception of ageing. These factors interact, strengthening and weakening, affecting the perception and assessment of menopause [3].

However, the literature is dominated by research that clearly indicates a relationship between intense menopausal symptoms and poor quality of life $[4,5]$.
The issue of quality of life $(\mathrm{QoL})$ in medical sciences refers to the general definition of health assumed by the World Health Organization as the state of mental, physical and social well-being and not merely lack of an illness or ailment $[6,7]$. Health-related quality of life (HRQoL) is a functional effect of an illness and its treatment that can be defined as a subjective assessment of life as a whole that includes both the assessment of physical and cognitive, emotional as well as social performance $[8,9]$.

\section{Material and methods}

The aim of the study was to assess dependencies between the intensity of menopausal symptoms and the quality of life in women aged 48-55 who do not use hormonal replacement therapy and the effect of chronic diseases on the quality of life and menopausal symptoms intensity of the individuals researched. The study was also intended to estimate the influence of sociodemographic variables on the quality of life and 
intensity of menopausal symptoms in the women researched.

The population researched comprised 161 women from the Lublin region who do not use hormonal replacement therapy. Respondents were from 48 to 55 years old; 83 of them (52\%) were $48-51$ years old, and 78 (48\%) were $52-55$ years old. Women whose last menstruation had occurred within 1-2 years before constituted the most numerous group. A total of $37.9 \%$ of women had last menstruated 2-5 years before and those whose last menstruation period had been more than five years before comprised the largest group (15.5\%).

The greatest number of the women had higher education (41\%), 40.4\% had vocational education, $16.1 \%$ had secondary education and $2.5 \%$ had primary education. More than half of the respondents (63.4\%) lived in urban areas and $36.6 \%$ of them were inhabitants of rural areas. Married women constituted a more numerous group (75.2\%) and a smaller group of $24.8 \%$ were single or widowed individuals.

The respondents lived mainly with a family (86.3\%) whereas $13.7 \%$ lived alone. The majority of the women (93.2\%) were professionally active, 3.7\% were unemployed and $3.1 \%$ were pensioners. In terms of financial status, the women most frequently rated it as good (73.3\%), $18.6 \%$ assessed it as very good and $8.1 \%$ as bad. A total of $63.4 \%$ of women were sexually active, whereas the remaining $36.6 \%$ did not have sexual intercourse. As far as concomitant diseases are concerned, 99 out of 161 individuals researched suffered from them. With regard to menopause, 143 women did not take any medications, whereas the remaining 28 patients took supplements.

The research method applied in the study was the diagnostic questionnaire. The research technique was an interview and the tools utilised included the BlattKupperman index (KI) and the scale used for the assessment of quality of life - WHOQOL-BREF.

Table 1. Intensity of menopausal symptoms measured with the Kupperman index

\begin{tabular}{lcc}
\hline Intensity of menopausal symptoms & $n$ & Percentage \\
\hline Moderate & 141 & 87.6 \\
\hline Moderately severe & 20 & 12.4 \\
\hline Severe & 0 & 0.0 \\
\hline Total & 161 & 100.0 \\
\hline
\end{tabular}

The $\mathrm{KI}$ comprises 11 items related to the assessment of menopausal symptoms i.e. intensity of hot flashes, profuse sweating, sleep disturbances, excessive nervousness, depressive mood, dizziness, lack of energy, articular pain, headaches, arrhythmia, paraesthesia. A respondent rates every item by assigning it some number of points depending on the intensity of the symptom (does not occur - 0 points, mild intensity -1 point, moderate intensity -2 points, severe intensity -3 points). Next, the points were added and the total determines the intensity rate of menopausal symptoms: moderate intensity - below 20 points, moderately severe intensity - 21-34 points and severe intensity -35 points and more.

The WHOQOL-BREF assesses quality of life of both healthy individuals and unhealthy ones in clinical practice. The instrument is concerned with such domains of life as physical health, psychological, social relationships and environment. The answers are presented on a five-point scale (from 1 to 5 points). The results in the given domain of life have a positive direction; namely, the greater the number of points, the higher the quality of life.

\section{Results}

A moderate intensity of menopausal symptoms measured with the $\mathrm{KI}$ was found in the majority of the women (87.6\%), moderately severe intensity regarded $12.4 \%$ of the individuals researched and none of the patients experienced severe intensity of the aforementioned symptoms (Table 1).

No relationship between the intensity of menopausal symptoms and the time that passed since the last menstruation period was observed ( $p=0.94573$ ).

Table 2 depicts the assessment of quality of life reported by the women researched in the given domains. The respondents rated their social relationships the highest (3.65), their general satisfaction with health was next (3.49), followed by their performance in the domain of environment (3.42). The lowest result was obtained in the area of physical health (3.14).

In the course of the research it was observed that the degree of menopausal symptoms intensity affects statistically significantly general satisfaction with health status ( $p=0.00002)$, physical health $(p=0.01)$, psychological domain $(p=0.0001)$ and environmental domain

Table 2. Assessment of quality of life in the women researched measured with the WHOQOL-BREF

\begin{tabular}{lccccc}
\hline Domain & Mean & Median & Minimum & Maximum & Standard deviation \\
\hline Physical health & 3.14 & 3.14 & 2.00 & 4.14 & 0.45 \\
\hline Psychological & 3.37 & 3.33 & 1.67 & 4.50 & 0.53 \\
\hline Social relationships & 3.65 & 3.67 & 2.00 & 5.00 & 0.77 \\
\hline Environment & 3.42 & 3.38 & 2.00 & 4.75 & 0.55 \\
\hline General satisfaction with health status & 3.49 & 3.50 & 2.15 & 4.77 & 0.54 \\
\hline
\end{tabular}


Table 3. Intensity of menopausal symptoms and assessment of quality of life

\begin{tabular}{|c|c|c|c|c|c|c|c|c|}
\hline Domain & $\begin{array}{l}\text { Degree of symptoms } \\
\text { intensity }\end{array}$ & Mean & Median & Minimum & Maximum & $\begin{array}{l}\text { Standard } \\
\text { deviation }\end{array}$ & $Z$ & $p$ \\
\hline \multirow[t]{2}{*}{ Physical health } & Moderate & 3.18 & 3.14 & 2 & 4.14 & 0.45 & 2.64 & 0.01 \\
\hline & Moderately severe & 2.91 & 2.86 & 2.29 & 3.57 & 0.37 & & \\
\hline \multirow[t]{2}{*}{ Psychological } & Moderate & 3.41 & 3.5 & 1.67 & 4.5 & 0.53 & 3.26 & 0.001 \\
\hline & Moderately severe & 3.02 & 3 & 2.17 & 4 & 0.46 & & \\
\hline \multirow[t]{2}{*}{ Social relations } & Moderate & 3.69 & 3.67 & 2 & 5 & 0.76 & 1.45 & 0.15 \\
\hline & Moderately severe & 3.42 & 3.33 & 2 & 5 & 0.84 & & \\
\hline \multirow[t]{2}{*}{ Environment } & Moderate & 3.46 & 3.5 & 2.25 & 4.75 & 0.55 & 2.65 & 0.01 \\
\hline & Moderately severe & 3.1 & 3.19 & 2 & 4 & 0.49 & & \\
\hline \multirow{2}{*}{$\begin{array}{l}\text { General satisfaction } \\
\text { with health status }\end{array}$} & Moderate & 3.56 & 3.54 & 2.42 & 4.77 & 0.52 & 4.31 & 0.00002 \\
\hline & Moderately severe & 2.99 & 3.06 & 2.15 & 3.73 & 0.42 & & \\
\hline
\end{tabular}

$(p=0.01)$, but does not have a statistically significant effect on social relationships ( $p=0.15$ ) (Table 3 ).

The assessment of quality of life did not prove to be statistically significant with regard to the place of residence (urban areas, rural areas) living alone or with a family as well as being single or in a relationship (husband, partner).

A statistically significant dependency was proved between the professional status of the individuals researched and the assessment of quality of life in the following domains: physical health $(p=0.050)$, psychological $(p=0.0019)$, environment $(p=0.0010)$, social relationships $(p=0.00056)$ and general satisfaction with health status $(p=0.0008)$. Professionally active respondents rated their quality of life the highest, followed by the unemployed women, whereas pensioners rated it the lowest.

A very good financial situation of the respondents turned out to have a statistically significant effect on the assessment of quality of life in all domains, i.e. physical health $(p=0.0002)$, psychological $(p=0.0004)$, social relationships ( $p=0.0019)$, environment $(p=0.0000)$ as well as general satisfaction with health status $(p=0.0000)$.

A relationship between the women's higher education level and performance in the domain of environment $(p=0.0034)$ was found.

The respondents who were sexually active obtained significantly higher mean results in all domains of life and general satisfaction with health status compared to those who were not sexually active: physical health $(p=0.02)$, psychological $(p=0.0004)$, social relationships $(p=0.000000)$, environment $(p=0.00003)$ and general satisfaction with health $(p=0.00001)$.

\section{Health status of the respondents}

Chronic diseases that affected the respondents included hypertension (83.3\%), osteoporosis (16.7\%), ischaemic heart disease $(14.1 \%)$ and diabetes $(12.8 \%)$ (Table 4).
It was observed that diabetes had a statistically significant effect on the intensity of menopausal symptoms $(p=0.002875)$. Respondents suffering from diabetes rated their quality of life significantly lower compared to healthy ones including their performance in the following domains of life: physical health $(p=0.000924)$, environment $(p=0.014370)$ and general satisfaction with health status $(p=0.020624)$.

Ischaemic heart disease affected statistically significantly the quality of life of the individuals researched by decreasing it in the following domains: physical health $(p=0.020801)$, psychological $(p=0.003095)$, social relationships $(p=0.000991)$, environment $(p=0.019718)$ and general satisfaction with health status $(p=0.000665)$.

The respondents suffering from hypertension reported that the disease decreased their quality of life statistically significantly in the domain of physical health $(p=0.026112)$ and general satisfaction with health status $(p=0.007900)$. The women researched who were not affected by osteoporosis rated their quality of life statistically significantly higher compared to those with osteoporosis in all domains of life: physical health $(p=0.003438)$, psychological $(p=0.000536)$, social relationships $(p=0.003543)$, environment $(p=0.003438)$ and general satisfaction with health status $(p=0.000188)$. As far as the respondents' body weight presented with the BMI is concerned, $43.5 \%$ of

Table 4. Chronic diseases in the respondents

\begin{tabular}{llc}
\hline Chronic disease & $n$ & Percentage \\
\hline Diabetes & 10 & 12.8 \\
\hline Ischaemic heart disease & 11 & 14.1 \\
\hline Hypertension & 64 & 83.3 \\
\hline Osteoporosis & 13 & 16.7 \\
\hline Total & 99 & $126^{*}$ \\
\hline *Some respondents reported more than one chronic disease
\end{tabular}


the women were overweight, $34.8 \%$ presented proper weight, $17.4 \%$ had type I obesity and $4.3 \%$ had type II obesity.

\section{Discussion}

The changes that a women's body undergoes in the menopause cause various health problems. They are concerned with both physical and mental health. The degree and character of the ailments depend on an individual. Although menopause is universal, every women has her own experiences. Undoubtedly, menopause affects the assessment of quality of life $[4,6]$.

Due to popularised health education on menopause and access to information, women's knowledge on menopause has improved in recent years. Women know more and more about that period of life and thanks to this can be more effective in dealing with menopausal symptoms and complications [4].

The patients I studied did not use hormone replacement therapy. A small proportion (28 out of 161) were taking menopause-dedicated dietary supplements. In the Paszkowski and Skrzypulec-Plin research, the herbal preparation Femelis Meno, after one month of treatment, showed significant improvement with respect to such parameters as hot flushes/sweating, irritability, sexual problems and bladder problems [10].

In the course of the research, the respondents rated their quality of life averagely for three out of five points. They assessed their quality of life in the domain of social relationships the highest and in the domain of physical health the lowest. Similar findings were obtained by Krajewska-Ferishah et al. [11]. A total of $87.6 \%$ of the women presented a moderate intensity of menopausal symptoms according to the $\mathrm{KI}$ and $12.4 \%$ of them reported a moderately severe intensity of symptoms associated with menopause.

In the course of the authors' own research, the effect of menopausal symptoms intensity on the quality of life was confirmed [12].

According to Czarnecka-Iwańczuk et al., women who present somatic symptoms of menopause rate their quality of life lower [13]. Shyu et al. highlight that the fact of entering the menopausal period increases the probability of a decrease in quality of life [14].

Hunter and Rendall emphasise that women with higher education, which can result in a more favourable professional situation, reported their menopausal symptoms as less intense or irritating [15].

The aforementioned results were confirmed in the authors' own research - the women with higher education level assessed their quality of life as better compared to those with secondary, vocational or primary education level.
Numerous authors including Elavsky have conducted research in which poor performance in the psychological domain was observed in menopausal women who reported a worse financial status, were professionally inactive and lived alone [16].

Skrzypulec et al. proved that lack of professional activity favours the intensity of vasomotor symptoms and generally decreased quality of life. Single women of bad financial status were affected by the most intense symptoms [17]. A similar association was found in the authors' own research; namely individuals with a bad financial status who were professionally inactive rated their quality of life as worse in the following domains: psychological, physical health, environment, social relationships and general satisfaction with health in comparison to the women who worked professionally and reported a good/very good material status.

In the course of the authors' own research, sexually active women obtained a mean, statistically significantly higher result in all domains of quality of life and general satisfaction with health. In the research by Astbury et al. it was observed that less intense menopausal symptoms and higher quality of life was were found in married women [18], particularly those who reported a good sexual relationship with the partner (which was not confirmed in the authors' own research). The research by Banaszek and Saracen proved a relationship between the time when the last menstruation period occurred and the intensity of menopausal symptoms, which was not confirmed in the authors' own research [19].

Lipid metabolism changes as a result of a drop in the levels of oestrogen in menopausal women, which favours both overweight and obesity. According to the authors' own research, $43.5 \%$ of the respondents suffered from overweight and $21.7 \%$ presented type I and II obesity. Multi-centre studies confirm that BMI has a significant effect on decreased quality of life in the domain of physical health, psychological and sexual performance [20-23].

\section{Conclusions}

The quality of life positively correlated with the intensity of menopausal symptoms - a lower severity of menopause symptoms resulted in a higher quality of life.

Factors such as the employment of surveyed women, good financial status and sexual activity resulted in a higher quality of life of women during menopause.

The occurrence of chronic hypertension, ischaemic heart disease, diabetes and osteoporosis in the studied chronic diseases resulted in a lower quality of life.

\section{Disclosure}

The authors report no conflict of interest. 


\section{References}

1. Kaczmarek M. The timing of natural menopause in Poland and associated factors. Maturitas 2007; 57: 139-145.

2. Warenik-Szymankiewicz A, Męczalski B. Neuroendokrynne uwarunkowania menopauzy. Ginekologia Polska 1998; 68: 620-260.

3. Stachoń AJ. Ocena odczuwania wybranych objawów w zależności od fazy klimakterium i charakteru menopauzy. Prz Menopauzalny 2013; 4: 315-320.

4. Chiu YW, Moore RW, Hsu CE, et al. Factors influencing women's quality on life in the later half of life. Climacteric 2008; 11: 201-211.

5. Conde DM, Pinto-Neto AM, Santos-Sá D, et al. Factors associated with quality of life in a cohort of postmenopausal women. Gynecol Endocrinol 2006; 22: 441-446.

6. Gojdź K, Bąk-Sosnowska M, Kołodziej S. Jakość życia kobiet w wieku 45-55 lat. Prz Menopauzalny 2013; 3: 213-215.

7. The World Health Organization Quality of Life assessment (WHOQoL): development and general psychometric properties. Soc Sci Med 1988; 46: 1569-1585.

8. Trzebiatowski J. Jakość życia w perspektywie nauk społecznych i medycznych - systematyzacja ujęć definicyjnych. Hygeia Public Health 2011; 46: 25-31.

9. Uchmanowicz I, Łoboz-Grudzień K. Jakość życia - definicje i narzędzia badawcze - przegląd literatury. Fam Med Prim Care Rev 2008; 10: 245-252.

10. Paszkowski T, Skrzypulec-Plinta V. Assessment of quality of life in women using Femelis Meno. Prz Menopauzalny 2018; 17: 77-85.

11. Krajewska-Ferishah K, Krajewska-Kułak E, Terlikowski S, et al. Analysis of quality of life of women in menopause period in Poland. Greece and Belarus and Belgium using MRS scale. A multicenter study. Adv Med Sci 2010; 55: 191-195.

12. Orzechowska A, Typel D, Wysokiński A, et al. Funkcjonowanie psychospołeczne kobiet w okresie klimakterium. Psychiatr Pol 2007; 3: 293-301.

13. Czarnecka-Iwańczuk M, Stanisławska-Kubiak M, Mojs E, et al. Objawy menopauzy. a satysfakcja z życia i samoocena wśród kobiet. Prz Menopauzalny 2012; 6: 468-473.

14. Shyu YK, Pan CH, Liu WM, et al. Health-related quality of life and healthcare resource utilization in Taiwanese women with menopausal symptoms: A nation-wide survey. J Nurs Res 2012; 20: 208-218.

15. Hunter M, Rendall M. Bio-psycho-socio-cultural perspectives on menopause. Best Pract Res Clin Obstet Gynaecol 2007; 21 : 261-274.

16. Elavsky S. Physical activity, menopause and quality of life: the role of affect and self-worth across time. Menopause 2009; 16: 265-271.

17. Skrzypulec V, Naworska B, Drosdzol A. Analiza wpływu objawów klimakterycznych na funkcjonowanie i jakość życia kobiet w okresie okołomenopauzalnym. Prz Menopauzalny 2007; 11: 96-101.

18. Astbury J. Mental health aspects of women's reproductive health. A global review of the literature. World Health Organization, Geneva 2009.

19. Banaczek Z, Saracen A. Satysfakcja życia i samoocena wśród kobiet w okresie menopauzy. Wiad Lek 2016; 69: 174-179.

20. Llaneza P, Ińarrea J, Gonzalez C, et al. Differences in health related quality of life in a sample of Spanish menopausal women with and without obesity. Maturitas 2007; 58: 387-394.

21. Obara-Gołębiowska M. Quality of life in obesity at perimenopausal age in obese women and women with proper body mass index. Health Prob Civil 2018; 12: 151-156.

22. Pace G, Silvestri V, Gualá L, Vicentini C. Body mass index. urinary incontinence. and female sexual dysfunction: how they affect female postmenopausal health. Menopause 2009; 16: 1188-1192.

23. Tkaczuk-Włach J, Włach R, Sobstyl M, et al. Otyłość w okresie okołoi pomenopauzalnym. Prz Menopauzalny 2012; 6: 514-517. 